\title{
Influence of Establishment Methods on Yield and Yield Parameters of Finger Millet (Eleusine Coracana L. Gaertn) in Ward 24, Zaka District
}

\author{
Nyasha Sakadzo ${ }^{1}$, Gift Bvekwa ${ }^{1} \&$ Kasirayi Makaza ${ }^{1}$ \\ ${ }^{1}$ Department of Soil and Plant Sciences, Faculty of Agricultural and Natural Sciences, Great Zimbabwe \\ University, Zimbabwe \\ Correspondence: Nyasha Sakadzo, Department of Soil and Plant Sciences. Faculty of Agricultural and Natural \\ Sciences, Great Zimbabwe University, P.O. Box 1235 Masvingo. Zimbabwe. Tel: 263-775-985-724. E-mail: \\ nsakadzo87@gmail.com
}

Received: December 7, 2019 Accepted: December 27, 2019 Online Published: January 1, 2020

\begin{abstract}
Finger millet is a climate compliant crop; its production remains low due to poor establishment methods. A field experiment was conducted during the rainy season of 2018/19 at Dorcas Charare plot in ward 24, Zaka district to investigate the effects of establishment methods on yield and yield parameters of finger millet (Eleusine coracana L. Gaertn). The experiment was laid out in a Randomized Complete Block Design (RCBD) with three treatments namely broadcasting, hand drilling and transplanting replicated three times. Results on grain yield showed that transplanting method had the highest yield of $0.51 \mathrm{t} / \mathrm{ha}$ whilst drilling and broadcasting scored $0.40 \mathrm{t} / \mathrm{ha}$ and $0.35 \mathrm{t} / \mathrm{ha}$ respectively. Transplanting method significantly $(\mathrm{p}<0.05)$ influenced higher number of tillers (7.13) per hill followed by drilling (2.40) and lastly broadcasting (2.13). Significant differences $(p<0.05)$ were noted on panicle number with transplanting scoring the highest (8.13) and broadcasting the lowest (3.13). It can be concluded from the study that transplanting method realized a higher panicle number, tiller number and grain yield. Farmers must adopt transplanting as an establishment method in finger millet production.
\end{abstract}

Keywords: finger millet, panicle number, hill, climate, compliant, yield, broadcasting, drilling

\section{Introduction and Background}

Finger millet (Eleusine coracana L. Gaertn) belongs to family Poaceae (Nepal Agricultural Research Council, 2014). It is an annual herbaceous plant widely grown as a cereal crop in the arid and semiarid areas of Africa and Asia. It is a tetraploid and self-pollinating species probably evolved from its wild relative Eleusine Africana $\mathrm{L}$. (Adunga et al., 2011). Finger millet is a tufted annual cereal crop growing $40-150 \mathrm{~cm}$ tall, taking between 2.5 and 6 months to mature. It is a short-day plant with a growing optimum 12 hours of daylight for most varieties (Adunga et al., 2011). . It has narrow, grass like leaves and many tillers and branches. The head consists of a group of digitately arranged spikes. Finger millet is grown for its edible seeds. The seeds, which may be white, light brown, or dark brown, are consumed in a variety of forms including as unleavened bread made from milled flour. Various types of porridge and alcoholic beverages are also prepared from the seeds (Alumira and Rusike, 2005).

Finger millet originated in East Africa (Ethiopian and Ugandan highlands) and was introduced in India around 2000 BCE. It was claimed to have been found in an Indian archaeological site dated to 1800 BCE (late Iron age) (Bayala et al., 2002). According to Bayala et al. (2002), the oldest record of it from an archaeological site is from Africa 8th century AD. Interesting crop characteristics of finger millet are the ability to withstand cultivation at altitudes over $2000 \mathrm{~m}$ above sea level, its high drought tolerance, and the long storage time of the grain. It is an important food cereal crop of semi-arid tropics particularly by communal small scale and subsistence farmers under dry-land production.

The main growing area of finger millet ranges from $20^{\circ} \mathrm{N}$ to $20^{\circ} \mathrm{S}$, meaning mainly the semiarid to arid tropics. Nevertheless, finger millet is found to be grown at $30^{\circ} \mathrm{N}$ in the Himalaya region (India and Nepal) (Bayala et al., 2002). According to Beddington (2010a), the majority of worldwide finger millet farmers grew it under rain fed conditions, although yields often can be significantly improved when irrigation is applied. Heat tolerance of finger millet is high. For most finger millet varieties, the optimal average growth temperature is about $27^{\circ} \mathrm{C}$, 
while the minimal temperatures should not be lower than $18^{\circ} \mathrm{C}$ (Beddington, 2010a). Relative to other species (pearl millet and sorghum), finger millet has a higher tolerance to cool temperatures (Beddington, 2010b).

Devi and Sathyabama (2014) postulates that finger millet is important for its nutritional value in the diet of people. The grain is high in dietary fiber and calcium. It also has medicinal attributes and used by diverse communities for making special foods for diabetics, gluten free food for people suffering from celiac disease and weaning food for infants (Cgiar, 2011). Finger millet contain nutritionally important starch fraction, which are slowly digested, absorbed and favourable in diet pattern for metabolic disorders such as diabetes, hypertension, and obesity (Devi and Sathyabama, 2014).

The grain by proportion contains $9.2 \%$ proteins, $1.29 \%$ fats, $76.32 \%$ carbohydrates, $2.2 \%$ mineral, $3.90 \%$ ash, $0.33 \%$ calcium (Beddington, 2010b). Vitamin A, B and phosphorous are also present in smaller quantities. Iodine content in finger millet is reported to be the highest among food grain (Carletto and Banerjee, 2014). Finger millet taste better than most other cereals (Cgiar, 2011). It has no major pest problem and so can be stored cheaply for a long time (Bayala et al., 2002). The straw has an immense utility as fodder for both draught and milk animals. It makes good fodder and contain up to $61 \%$ of total digestible nutrients (Cgiar, 2011).

According to Devi and Sathyabama (2014), finger millet is a lost crop. It is an orphan crop because very little research has been done towards its production in Zimbabwe. Those who try to grow finger millet usually obtain low yields possibly due to lack of certified seeds and poor agronomic practices (Beddington, 2010b). A notable agronomic practice responsible for low yield of finger millet is lack of suitable establishment method under dry-land conditions (Chandan, 2018). While broadcasting is the widely adopted planting method of finger millet production in Zimbabwe including Zaka district, information on the other methods like transplanting and hand drilling is scant. Therefore, the study seeks to assess the influence of different establishment methods (broadcasting, drilling and transplanting) on grain yield and yield parameters of finger millet.

\section{Materials and Methods}

\subsection{Study site}

The experiment was carried out at Dorcas Charare's demonstration plot in ward 24 of Zaka district with the GPS coordinates: Latitude: 20.466723; Longitude: 31.4736366 . The site is located $5 \mathrm{~km}$ east of Jerera growth point. The area receives a total of $561.7 \mathrm{~mm}$ rainfall per annum that was unimodal from November 2018 to April 2019. Rainfall in this area is usually poorly distributed and thus naturally falls under natural region IV which is frequented by mid-season dry spell and droughts.

Temperature ranges from minimum $16^{\circ} \mathrm{C}$ to maximum $28^{\circ} \mathrm{C}$ under normal conditions, with some chances of dropping to less than $10^{\circ} \mathrm{C}$ in the coldest month of July and rising to above $35^{\circ} \mathrm{C}$ especially in October month. It has light sandy loam soils with a moderate depth approximately $1 \mathrm{~m}$ with some pockets of sodicity in surrounding areas. The soil is inherently infertile with a gentle sloping and good drainage to support crop production. In order to realise good harvest farmers, nourish the soil with adequate manure and fertilizer. The land has been under cultivation of food crops with fertilizer and manure use. Crops grown include maize, groundnuts, cow peas, sesame and sweat potatoes entirely on dry land conditions (ZimVAC, 2019). 


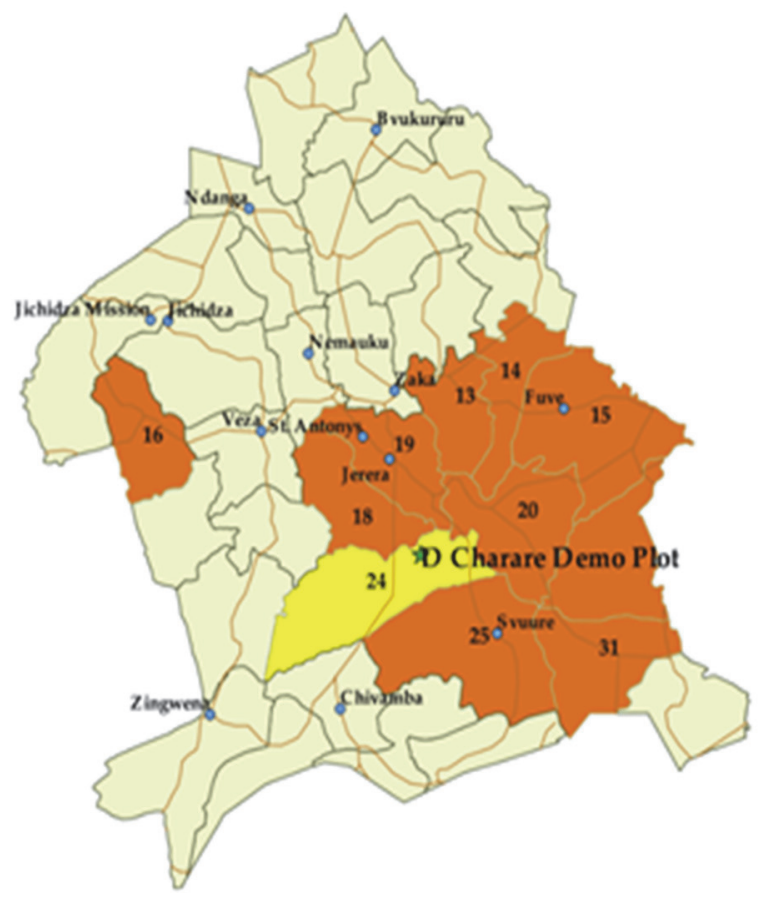

Figure 1. Study site

\subsection{Experimental Design}

A Randomized Complete Block Design (RCBD) replicated three times was used. Three treatments namely Broadcasting, Drilling and Transplanting establishment methods were used giving a total of nine plots covering an area of $128 \mathrm{~m}^{2}$. Slope was the blocking factor. Each of the three replications had three plots measuring $5 \mathrm{~m}$ by $2 \mathrm{~m}$ each which is the same as that by Dida et al. (2008) in an experiment conducted to determine population structure and diversity in finger millet (Eleusine coracana L. Gaertn) germplasm. The finger millet variety used in the experiment was FMV1The distance between blocks was $1 \mathrm{~m}$ and a $0.5 \mathrm{~m}$ between the individual plots within a block. The experiment gross plot area was $128 \mathrm{~m}^{2}$ and a net plot area of $27 \mathrm{~m}^{2}$.

Show a table with treatment combinations

Table 1. Treatment description

\begin{tabular}{lll}
\hline \multicolumn{3}{c}{ Treatment } \\
\hline T1 & T2 & T3 \\
Broadcasting & Drilling & Transplanting \\
\hline
\end{tabular}

\subsection{Plot Management/ Agronomic Practices}

\section{Land preparation}

The land was prepared early in May 2018 by ploughing using an ox-drawn mouldboard plough. This was done to burry trash and allow for decomposition. A second ploughing was done in November 2018 when a total rainfall of $20 \mathrm{~mm}$ was received. Some 0.1 tonnes of well rotten farmyard manure was applied before second ploughing to improve soil fertility. In smallholder and subsistent farming practices, ploughing is usually done using an ox-drawn plough (McDonald, 2015). A fine tilth in the seedbed was achieved by light harrowing to improve soil seed contact and ensure good germination of the small finger millet grains.

\section{Planting}

Dry planting was adopted as recommended by Stacey et al. (2012). The seed was mixed with fine river sand before planting. This was recommended by Alumira and Rusike (2005) so as to reduce wastage due to over application since the grains are too small. According to FAO (2015), a seed rate of $5 \mathrm{~kg} / \mathrm{ha}$ is recommended for dry land small 
grain production. In this study, 100g of FMV1 seed was planted by hand on all broadcasting and drilling plots. The nursery bed was also planted on the same day as drilling and broadcasting plots. Drill lines were spaced at $40 \mathrm{~cm}$ to get a maximum of five lines per plot as used by Alumira and Rusike (2005). The seed was covered by dragging a branch of tree across the planted area to allow a thin film of soil on the planted seeds. The first effective rains were received in December with a total of $94.8 \mathrm{~mm}$.

\section{Transplanting and thinning}

Transplanting was done after three weeks from crop emergence when the plants had attained four leaves of growth. Seedlings from the nursery bed were planted on the transplanting treatment plots at $40 \mathrm{~cm}$ inter-row and $10 \mathrm{~cm}$ in-row spacings on the same day when there was adequate moisture in the soil. On the same day, thinning of plants from the broadcasting and drilling plots was accomplished to attain a plant population of 250 plants per plot which corresponds to the recommended finger millet plant population of 250000 plants per hectare by Agricultural research (2012) and Chandan (2018). Plant population from individual plots was the same for all treatments; with broadcasting adopting a scattered spacing format.

\section{Weed management}

Weeds can seriously affect yields if not controlled and therefore first weeding should be done 2-3 weeks after emergence and second weeding 2 weeks after the first weeding (Agricultural Research, 2012). In this experiment, mechanical and hand pulling weeding was done to control weeds. A total of four weeding regimes were undertaken. The first weeding was done 2 weeks after crop emergence to destroy early weeds while the second and third weeding at peak vegetative growth stage and at flowering respectively. The fourth weeding was a cleaning exercise at physiological maturity stage to destroy late weeds and allow weed free plots for easy harvesting. The common weeds found were Richadia scabra, Eleusine indica, Bidens pillosa and Galinsoga parviflora.

\section{Fertilizer application}

The field was fallowed for one season which means, it was last cultivated in 2016 for groundnut crop production. Some 0.1 tonnes of farmyard manure was applied uniformly on the experiment plots at a rate of 8 tons/ha as recommended by FAO (2015) in order to improve the soil organic matter content, moisture retention ability and soil structure. As recommended by Fetene et al. (2011), 3kg fertilizer compound D fertiliser (7:14:7) was used as basal dressing before planting. This amount translates to an acceptable rate of $200 \mathrm{~kg} / \mathrm{ha}$ also recommended by Ebanyat et al. (2010).

The recommended rate of fertilizer Ammonium Nitrate (AN) for top dressing is $150 \mathrm{~kg} / \mathrm{ha}$ according to Ebanyat et al. (2010). According to this rate, $2 \mathrm{~kg}$ AN fertilizer was split applied on this experiment since the soil was sandy loam with some high chances of leaching caused by cyclone Idai excessive rains experienced mid-season. The $1^{\text {st }}$ half amount of AN application was done at the 5-6 leaf stage and the other half at flowering. The same type and amount of fertilizers was applied in all the treatments in the experiment.

\section{Pest and disease management}

The common pests encountered were aphids and some caterpillars of the species Helianthus. These were noticed during scouting at vegetative and flowering stages. Control was done by means of spraying Carbaryl 85 WP and dimethoate $40 \mathrm{EC}$ at recommended label rates. Some ladybird beetles were also noticed but were beneficial in the biological control of aphids. Proper management of weeds also helped to reduce pest incidences. Pest control was uniform across all the treatments to reduce bias of results as supported by Cgiar (2011) and FAO (2016).

\section{Data collection}

The following data was collected and recorded to the required format by the hired and trained lead farmer; plant height, number of tillers formed, panicle length, panicle number grain yield.

\section{Plant height}

Data on plant height was taken from the five randomly selected plants in the net plots and measured using a transparent meter ruler from 14 days after emergence and /or transplanting followed by subsequent two weeks intervals until the plants matured at 98 days. At this period there was no more increase in plant height. The measurements were taken from ground level up to the plant tip.

\section{Number of tillers formed}

The number of tillers per plant of the selected plants per treatment was counted after an initial thinning of the broadcasting and drilling plots to the required plant population. The number of tillers was counted at intervals of 
two weeks until when there was no more increase in tillers formed.

\section{Length of heads formed (Panicle length)}

The length of panicles for the randomly selected plants were measured at 2 weeks from head emergence until the panicles reached physiological maturity when there was no more elongation of the panicles.

\section{Number of heads formed (panicle number)}

Number of heads formed was counted once after the plants reached physiological maturity at 90 days.

\section{Grain yield}

Grain yield was measured at the end of the study period where all heads were harvested from the net plots of all the treatments when the crop reached physiological maturity. Selected plots of each treatment (broadcasting, drilling and transplanting) were individually harvested to obtain the actual yield per each treatment plot. After threshing and winnowing, the grain from each of the three individual treatments was weighed. Again, grain from all broadcasting plots, all drilling plots and all transplanting plots was weighed using an electronic scale. Average yield in tonnes per hectare for the three treatments under study was obtained and the data was taken for analysis.

\section{Statistical Data Analysis}

The collected data was subjected to Analysis of Variance (ANOVA) using GenStat 14.1, Copyright 2011; VNS, International Ltd. Mean separation was done by using Fisher's protected least significance test at $5 \%$ significance level.

\section{Results}

Table 2. Results of yield and yield components

\begin{tabular}{lcccccc}
$\begin{array}{c}\text { Parameter } \\
\text { Treatment }\end{array}$ & $\begin{array}{l}\text { Plant height } \\
\text { 14Wks (cm) }\end{array}$ & $\begin{array}{l}\text { No. of tillers per } \\
\text { plant }\end{array}$ & $\begin{array}{l}\text { No. of Panicle } \\
\text { per plant }\end{array}$ & $\begin{array}{l}\text { Panicle length } \\
(\mathbf{c m})\end{array}$ & $\begin{array}{l}\text { Grain } \\
\left(\text { tha }^{-1}\right)\end{array}$ \\
\hline Broadcasting & $80.73^{\mathrm{a}}$ & $2.13^{\mathrm{a}}$ & $3.13^{\mathrm{a}}$ & $9.47^{\mathrm{a}}$ & $0.35^{\mathrm{a}}$ \\
Drilling & $85.80^{\mathrm{b}}$ & $2.40^{\mathrm{a}}$ & $3.40^{\mathrm{a}}$ & $10.15^{\mathrm{a}}$ & $0.40^{\mathrm{b}}$ \\
Transplanting & $88.60^{\mathrm{bc}}$ & $7.13^{\mathrm{b}}$ & $8.13^{\mathrm{b}}$ & $11.46^{\mathrm{b}}$ & $0.51^{\mathrm{c}}$ \\
Grand mean & 85.04 & 3.89 & 4.89 & 10.36 & 3.967 \\
LSD & 4.12 & 0.639 & 0.639 & 0.931 & 0.275 \\
p-Value & 0.009 & $<0.001$ & $<0.001$ & 0.005 & $<0.001$ \\
CV \% & 2.4 & 8.2 & 6.5 & 4.5 & 3.5 \\
\hline
\end{tabular}

\section{Effects of finger millet establishment methods on mean plant height}

The mean plant height for drilled plants was significantly higher $(\mathrm{p}=0.009)$ than that for broadcasted plants though not significantly different from the mean plant height for transplanted plants. Transplanting method recorded the highest plant height $(88.6 \mathrm{~cm})$ whilst broadcasting recorded the lowest $(80.73 \mathrm{~cm})$ plant height.

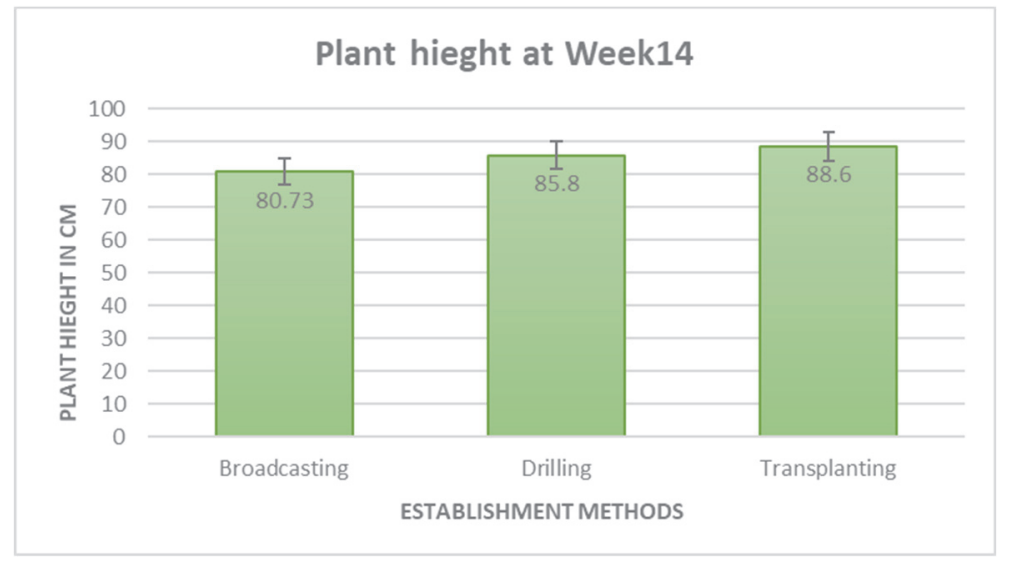

Figure 2. Effects of establishment methods on finger millet plant height 


\section{Effects of finger millet establishment methods on tiller number per plant.}

There were significant differences $(p<0.05)$ in mean number of tillers per plant amongst the three treatments. Transplanted plants recorded the highest mean number of tillers per plant (7.13) than both drilling and broadcasting which recorded 2.4 and 2.13 respectively. However, the mean number of tillers per plant for broadcasting and drilling were not significantly different $(\mathrm{p}<0.05)$.

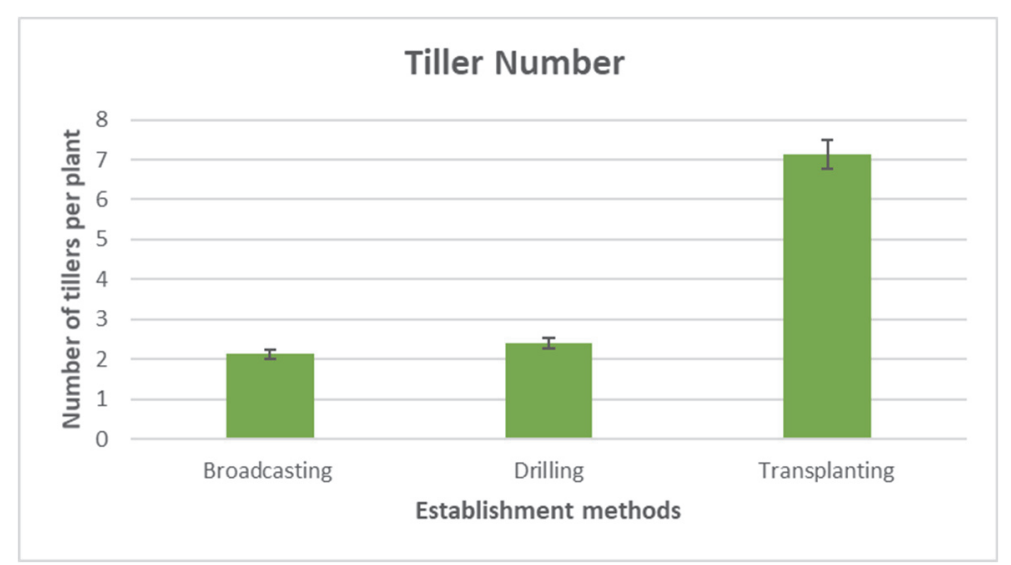

Figure 3. Effects of establishment methods on tiller number per plant of finger millet.

\section{Effects of establishment methods on panicle number per plant of finger millet.}

The results showed that there were significant differences $(p<0.05)$ between transplanting and broadcasting on mean number of panicles formed per hill. Transplanting method recorded the highest (8.13) number of panicles per plant as compared to broadcasting method with the lowest (3.13) panicles per plant.

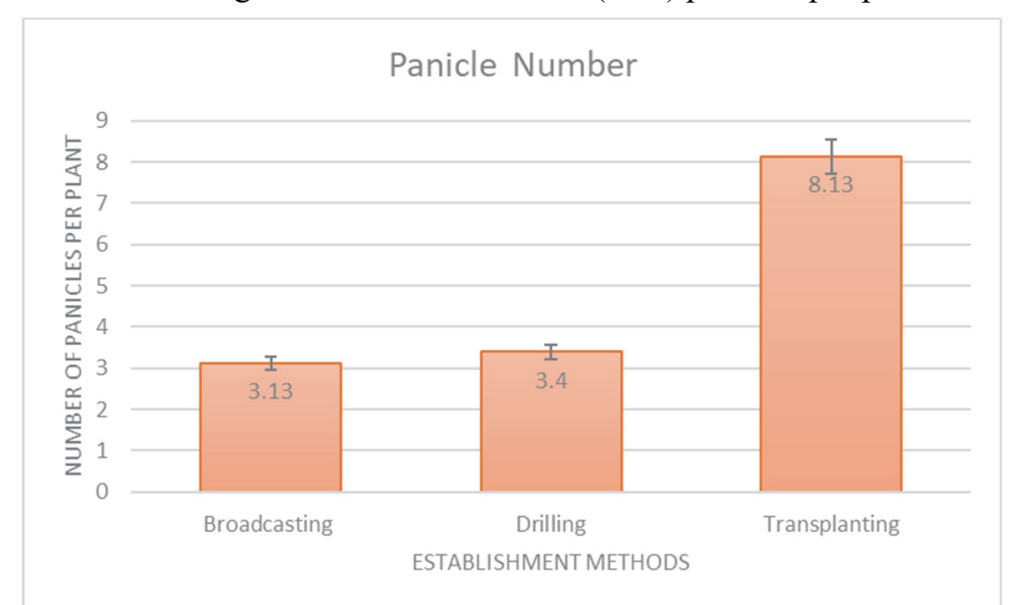

Figure 4. Effects of establishment methods on panicle number per plant of finger millet

\section{Effects of establishment methods on panicle length of finger millet}

Significant differences $(\mathrm{p}<0.05)$ on finger millet panicle length were recorded between transplanting and broadcasting methods. Transplanting method recorded the highest panicle length $(11.46 \mathrm{~cm})$ whilst broadcasting method recorded the lowest $(9.47 \mathrm{~cm})$ panicle length. There were no significant differences $(\mathrm{p}>0.05)$ on mean panicle length between drilling and broadcasting establishment methods. 


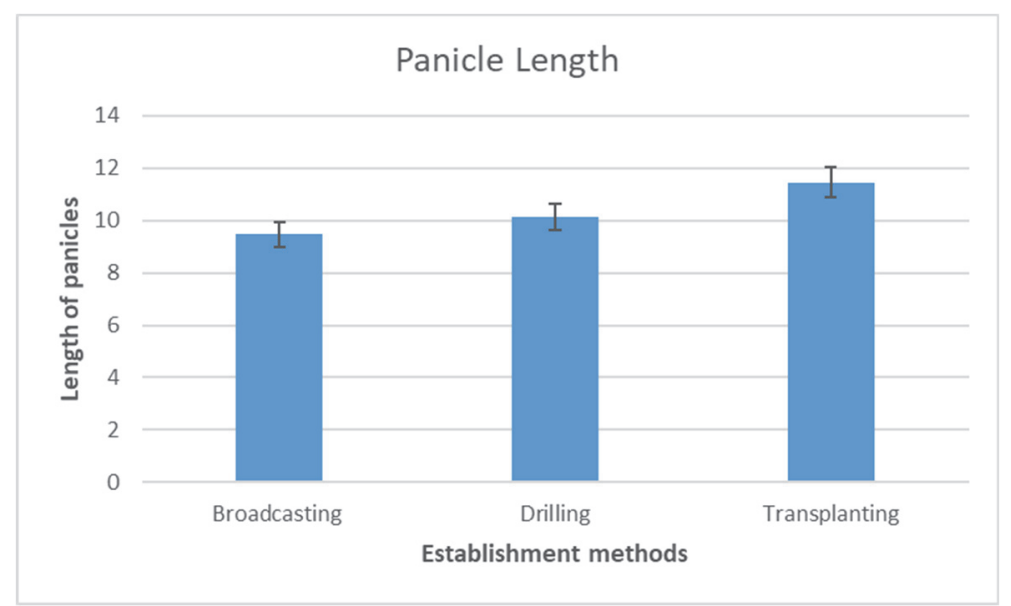

Figure 5. Effects of establishment methods on panicle length of finger millet

\section{Effects of establishment methods on finger millet grain yield}

Results showed that the mean grain yield of finger millet was significantly $(p<0.05)$ affected by establishment methods. The mean grain yield for drilled plants $\left(0.4\right.$ tha $\left.^{-1}\right)$ and transplanted plants $\left(0.51\right.$ tha $\left.^{-1}\right)$ were significantly higher than that of the control (broadcasted plants) with 0.35 tha $^{-1}$. The mean grain yield for the transplanted plants was significantly higher $(\mathrm{p}<0.05)$ than both drilled and broadcasted plants.

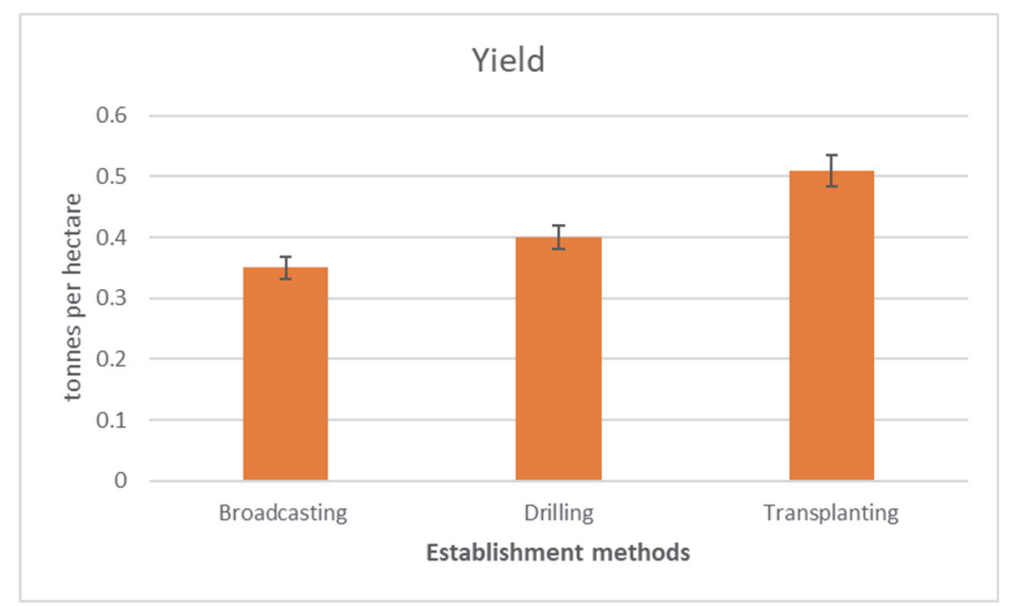

Figure 6. Effects of establishment methods on finger millet grain yield

\section{Discussion}

\section{Effects of establishment methods on finger millet plant height}

In situ methods of planting finger millet such as drilling and broadcasting recorded no significant differences on plant height. These results were in consonance with those of Maobe et al. (2014) and FAO (2016) in a similar experiment on effect of plant density, growth and grain yield of finger millet under high potential conditions in Kenya. Bhatta et al. (2017) reported contrasting results showing drilling being superior on plant height than transplanting but this was under high rainfall of $700 \mathrm{~mm}$ per annum. Transplanting recorded the highest plant height possibly because of vigorous growth attained when new roots developed after the transplanting shock. Bitew and Asargew (2014) states that vigorous root development induces plant growth and increased height. The increase in height on transplanted plants might be due to roots of finger millet plants having least competition under wider spacing so that growth is stimulated by sunlight and space for the canopy expansion. According to Dereji et al. (2016), plant height of finger millet was significantly influenced by spacing and it was maximum $(92.97 \mathrm{~cm})$ with $50 \mathrm{~cm}$ row spacing and followed by $40 \mathrm{~cm}$ row spacing $(91.84 \mathrm{~cm})$ in an experiment on influence of row spacing and seed rate on yield components of finger millet at Assosa zone in Benshagul Gumuze region of Ethiopia.

Effects of finger millet establishment methods on tiller number per plant 
The study revealed that transplanting method of planting was significantly $(p<0.001)$ superior over both drilling and broadcasting on tiller number. This can be attributed to more space between plants in transplanting method which gave a greater number of tillers per plant at all the growth stages as compared to drilled and broadcasted plants. The individual transplanted plants could have effectively utilized the available resources such as space, foraging area for root system, light utilization and thus enhanced the tiller production at wider spaced treatments. This can be attributed to more space between plants in transplanting method as compared to broadcasted and drilled plants. Sarawale et al. (2016) assets that tillering in cereal small grains can be induced by transplanting shock as well as wide spacing between individual plants. Drilling and broadcasting establishment methods did not differ significantly on tillering because the plants were planted in-situ and there was competition for growth in the first two weeks before thinning. This is supported by Maobe et al. (2014) in an experiment conducted under high potential conditions of Kisii highlands, southwest Kenya (KARI) which reported that transplanting in finger millet production induces tiller formation which also influences panicle number and grain yield. Awan et al. (2007), Kalaraju et al. (2011) and Dahal and Khadka (2012) recorded similar findings of increased number of tillers on transplanting method.

\section{Effects of establishment methods on panicle number per plant of finger millet}

Transplanted plants of finger millet resulted in significantly higher $(\mathrm{p}<0.001)$ mean number of panicles per hill than the drilled and broadcasted plants. Increase in panicle number from broadcasted plants, drilled to transplanted plants was 86,139 and 159 per cent respectively. This showed that transplanting establishment method of finger millet was superior on number of panicles compared to the drilling and broadcasting methods. The results showed that there were no significant differences on panicle number per hill between broadcasting (3.13a) and drilling (3.40a). This means tillering has a direct correlation on panicle number. The more the tillering the more the number of panicles. Similar findings were also reported by Gavit et al. (2017) in an experiment conducted to evaluate the effect of establishment techniques and sowing time on yield and yield attributes of Proso Millet. This is also in conformity with Herbal et al. (2018) in his experiment on comparing finger millet yield on different establishment method and fertilizer amounts in India showed that transplanted plants recorded highest number of panicles than broadcasted and drilled plants.

\section{Effects of establishment methods on panicle length of finger millet}

Panicle length is one of the important yield attributing parameters, which influenced the grain yield directly. The length of ear has a positive correlation with the number of grains per plant and ultimately on the grain yield of the crop (Chandan, 2018). The length of panicle was significantly different $(p<0.05)$ amongst the treatments. This might be due to higher moisture availability for transplanted plants owing to better moisture conservation and due to more vegetative growth resulting from efficient use of nutrients, water, radiation and increased metabolic activities. This is supported by Michaelraj and Shahmugam (2013) who asserts that length of panicles was found to be highest $(8.8 \mathrm{~cm})$ with transplanted plants and lowest $(6.5 \mathrm{~cm})$ with broadcasted plants. The results were also in conformity with those obtained by Suresh (2013) in an experiment on Integrated nitrogen management under different crop establishment methods in summer pearl millet (Pennisetum glaucum L.) under middle Gujarat conditions in India.

\section{Effect of establishment method on finger millet grain yield}

There was an increase in grain yield recorded under transplanting over that of broadcasting of seeds by 45.7 per cent. Also, increase in grain yield recorded in transplanting over drilling of seeds was 27.5 per cent. Similarly, increase in grain yield recorded in drilling over broadcasting of seeds was 14.3 per cent. These results were in conformity with Sarawale et al. (2016) in an experiment on effects of different varieties and establishment methods on growth and yield of finger millet under Konkan conditions in India. The increased yield attributes in transplanting establishment method might be due to increased growth and plant development resulting in increased yield attributes (Gavit et al., 2017). In addition, Bekele et al. (2016) reported similar findings for different spacing $(40 \mathrm{~cm} \times 10 \mathrm{~cm}, 30 \mathrm{~cm} \times 10 \mathrm{~cm}$ and $20 \mathrm{~cm} \times 10 \mathrm{~cm})$ on grain yield in an experiment conducted in Gumuz region of Ethiopia. Bekele et al. (2016) found that increasing the spacing led to increased tillering, panicle number and grain yield. This may have been attributed to more space between plants that resulted in higher number of tillers, panicle number and more grains from the wider spacing in transplanting compared to the closer spacing and scattered stands in broadcasting establishment method. The adverse effect of competition between plants associated with closer spacing and scattered stand may have been significant positively affecting yield in broadcasting establishment method.

\section{Conclusion}

From the results of this study, it can be concluded that the establishment methods that were tested does not have 
a significant effect on plant height. However, establishment method significantly influenced the number of tillers with broadcasting recording the least as compared to transplanting and drilling methods. Furthermore, grain yield was a function of tiller number, number of panicles and panicle length.

\section{Recommendations}

The researcher recommends farmers to adopt the transplanting method for finger millet production in Zaka District so as to realise high yield. However, further research is recommended to establish the correct plant population for optimum production as the current level of 250000 plants per hectare was inadequate for a conclusive determination of the exact plant population desirable for the finger millet variety FMV1.

\section{Conflicts of Interest}

Authors do not declare any conflicts of interest.

\section{References}

Adunga, A., Tesso, T., Degu, E., Tadesse, T., Merg, F., Lgesse, W., Tirfessa, A., Kidane, H., Wole, A., \& Dada, C. (2011). Genotype-by-environment interaction and yield suitability analysis in finger millet (Eleusine coracana L., Gaertn) in Ethiopia. American Journal of plant sciences, 2, 408-415.

Agricultural Research. (2012). Reviews pp.80-85; Edition 1.

Alumira, J., \& Rusike, J. (2005). The Green Revolution in Zimbabwe. Journal of Agricultural and Development Economics, 2(1), 50-66.

Awan, T. H., Ahamed, M., Ali, I., Anwar M., \& Mazoor, Z. (2007). Contribution of tillers

Bayala, J., Teklehaimanot, Z., \& Ouedraogo, S. J. (2002). Millet production under pruned Tree crowns in a parkland system in Burkina Faso. Agrofor.syst., 54, 203-214.

Be consistency on your referencing style if using APA $6^{\text {th }}$ style use it throughout the document and even intext. Follow journal requirements please.

Beddington, J. (2010a). Finger millet: A "certain crop for an "uncertain" future and a solution to food insecurity and hidden hunger under stress environments. Front plant science, 8, 643.

Beddington, J. (2010b). Food security: contributions from science to a new and greener revolution. Philos Trans. R. Soc. B.Biol.Sci., 365, 61-71. https://doi.org/10.1098/ rstb. 2009.0201 [PMC free article] [Pub Med] [Cross Ref].

Bekele, A. F., Getahun, D. W., \& Dereje A. B. (2016). Determination of Optimum Rates of Nitrogen and Phosphorus Fertilization for Finger Millet (Eleusine coracana L. Gaertn). Production at Assosa Zone, in Benishangul - Gumuz Region of Ethiopia. Advances in Sciences and Humanities, 2(1), 1-6. https://doi.org/10.11648/j.ash.20160201.11.

Bhatta, L. R., Subedi, R., Joshi, P., \& Gurung, S.B. (2017). Effect of Crop Establishment methods and Varieties on Tillering Habit, Growth Rate and Yield of Finger Millet. Agriculture Research and Technology: Open Access Journal, 11(5), 555826. https://doi.org/10. 19080/ARTDAJ 2017.

Bitew, Y., \& Asargew, F. (2014). Determination of seed rate and inter row spacing for finger-millet production (Eleusine coracana L.) in North Western Ethiopia. International Journal of Research and Review.

Carletto, Z., \& Banerjee. (2014). Toward a Better Measurement of Household and Food Security: Harmonizing indicators and the role of Household Survey. Global food Security, (2), 30-40. Retrieved from $\mathrm{https} /$ /researchgate.Net.

Cgiar. (2011). Kenya: new varieties boost finger millet harvest. Retrieved from https://www.cgiar.org/consortuim-news/kenya-newvarieties boost-finger- millet harvest/accessed

Chandan, K. (2018). Performance of Finger Millet (Eleusine coracana L.Gaertn) Under Different Crop Establishment Methods; Birsa University; Kanke Ranchi, India.

Dahal, R. K., \& Khadka, B. R. (2012). Performance of rice with varied age of seedlings and planting geometry under system of rice intensification (SRI) in farmer field in western Terai, Nepal. Nepal Journal of Science and Technology, 13(2), 1-6.

Devi, V., \& Sathyabama. (2014). Health benefits of finger millet (Eleusine Coracana L.). Polyphenols and dietary fiber: A review of Food Science Technology, 51. https://doi.org/1021-1040.100.1007/5 13197-11-0584-9. [PMC free article] [PubMed]. Retrieved from https//www.ncbi.ncm.nih.gov>pubmed. 
Dida, M. M., Wanyera, N., Dann, M. L. H., Bennetzen, J. L., \& Devos, K. M. (2008). Population structure and diversity in finger millet (Eleusine caracana L.) germplasm. Trop. Plant Biol., 1, 131-141.

Ebanyat, P., Ridder, N., de Jager, A., Delve, R. S., Bekunda, M. A., \& Giller, K. E. (2010). Impact of heterogeneity in soil fertility on legume-finger millet productivity, farmers targeting and economic benefits. Nutr.cycl Agroecosys, (87), 209-231.

Fetene, M., Okori, P., Gudu, S., Mneney, E., \& Tesfaye (2011). Delivering New Sorghum and Millet Innovation for Food Security and Improving Livelihoods in Eastern Africa. Nairobi, Kenya. International Livestock Research Institute (ILRI).

Food and Agriculture Organization (FAO). (2015). Sorghum and Millets in Human Nutrition. Rome, Italy.

Food and Agriculture Organization (FAO). (2016). Fertilizer use by crop in Zimbabwe. Rome, Italy.

Gavit, H. D., V. A., Rajemahadik, G. K., Bahure, M. S., Jadhav, T. N., Thorat, \& Kasture, M. C. (2017). Effect of Establishment Techniques and Sowing Time on Yield and Yield Attributes of Proso Millet (Panicum miliaceum L.). Int. J. Curr. Microbiol. App. Sci., 6(5), 1523-1528. https://doi.org/10.20546/ijcmas.2017.605.166.

Herbal, N., Ramachandrappa, M., \& Thimmegouda, M. N. (2018). Yield and Economics of Finger Millet with Establishment Methods Under Different Planting Geometry and Nutrient Source. Journal on Dryland Agricultural Research and Development, India.

Kalaraju, K., Kumar, D., Nagaraja, N., \& Ningappa, K. B. (2011). Effect of methods of planting on growth and yield of finger millet genotypes under organic farming. Research on Crops, 10(1), 20-24.

Maobe, S. N., Marth, K., Nyang'au, E. A., Basweti, Getabu, A., Mwangi, T. J., \& Ondicho, A. R. (2014). Effect of Plant Density on Growth and Grain Yield of Finger Millet in Southwest Kenya. World Journal of Agricultural Sciences, 10(6), 261-268.

Michaelraj, P. S. J., \& Shahmugam, A. (2013). A study on millets-based cultivation and consumption in India. International Journal of Marketing. Financial Services and Management Research, 2(4), 49-50.

NARC (2014). Released and registered crop varieties in Nepal.

Sarawale, P. P., Rajemahadik, V. A., Shendage, G. B., \& Mane, S. V. (2016). Effect of Different Varieties and Establishment Methods on Growth and Yield of Finger Millet Under Konkan Conditions in India.

Stacey, R., Birgit, M., Shahla, S., Anna D'Souza \& Nicholas, R. (2012). International Food Security Assessment, 2012-22. Economic Research Service.

Suresh, A. P. (2013). Integrated nitrogen management under different crop establishment methods in summer pearl millet (Pennisetum glaucum L.) under middle Gujarat condition. M.Sc. (Ag.) Thesis, Anand Agricultural University, Anand, Gujrat. within a rice plant to yield and yield components. Journal of Agricultural Resarch, 45(3), 237-243.

ZimVAC. (2019). Rural Livelihoods Assessment Report. Food and Nutrition Council housed at SIRDC:1574 Alpes Road, Hatcliffe, Harare.

\section{Copyrights}

Copyright for this article is retained by the author(s), with first publication rights granted to the journal.

This is an open-access article distributed under the terms and conditions of the Creative Commons Attribution license (http://creativecommons.org/licenses/by/4.0/). 